\title{
SOLIDÃO NEON
}

Renato Contente

Renato Contente (Recife, 1990) é jornalista, doutorando em sociologia e vive em São Paulo. 
Escrever é se vingar da perda.

Embora o material tenha se derretido todo, igual queijo fundido. (Waly Salomão, 1993) 
o ventilador

você sabe que recife

está um calor violento

e ainda assim entre nós

há desavenças por causa

do ventilador

preciso do vento no meu rosto

porque me desestabilizo com o

que não é constante

mas por você ele giraria

bateria nos pés

e voltaria à cabeça

para dela se afasta

acho que você

sentia frio em recife

talvez fossem as

madrugadas a marelas

do mercado da encruzilhada

hoje eu ta mbém giro o ventilador

coloco no mínimo e aprecio

as pausas sem vento no rosto

nu sob o cobertor eu penso

se recife não esfriou porque

você foi embora 


\section{a dedicatória}

eu queria te marcar e

te restavam poucos minutos no rosarinho

os táxis insistiam em ser cancelados e

ridiculamente chovia na rua sem saída

da casa amarela em que fomos felizes

teríamos sido realmente felizes ou

apenas curtimos a contento os latões de loló?

mas eu queria te marcar e o terceiro

táxi veio pra valer aí me apressei em

pegar o que na hora considerei ser

um souvenir especial de recife

um elepê com sucessos de reginaldo rossi

lamentei que não tinha desterro mas

assinei com data e um famigerado

para um amor no recife

eu não sei se lembras mas dias antes

teve paulinho da viola no pátio de são pedro

numa madrugada de carnaval chuvosa

como os teus últimos instantes na cidade

você indo eu entendi velozmente

com alguma ira mas mais tristeza

que não havia um amor no recife

a quem você pudesse evocar

o danço eu dança você era uma besteira

dado que só eu me requebrei sob

a dança da solidão 


\section{sex tape}

na última vez em que você

esteve dentro de mim eu

estava de quatro como você

preferia embora em mim

quase sempre doesse

esborrei a porra e você

achou bonito disse que

queria ter filmado como

já havíamos falado sobre

outras vezes mas nunca

chegamos a dar rec

talvez porque a instância

do nosso prazer não devesse

ser perturbada assim

e nossa intimidade isto

aquilo que nos era tão singular

não poderia ser captada mesmo

por câmeras frontais que ultrapassassem

doze megapixels de resolução

a gente se despedia sem saber

quem diria que nosso

gemidos selvagens eram na

verdade o linguajar primitivo

de um adeus desavisado 


\section{abocanhamento}

quem ama uma coisa selvagem

precisa estar apto a lidar com

isto é permitir que a pele

engrosse e conviver bem com

uma série de cortes alguns

superficiais outros atravessa-ossos

eu tentei meu deus

pêlos do par de olhos pretos

a noite encarnada

mas que sexo bonito
assim curvado adormecido

assim curvado adormecido
com o que sonham os sexos?

o coração da besta pulsava

despertar de um sonho perigoso

pairava por toda ela uma

catinga pestilenta acho que

um composto de sangue

escurecido suor fresco porra seca

súbito a besta desperta

os olhos pretos vibram

violenta mente e jogado no chão

exclamo em pensamento

que filho da puta

tinha me encurralado e ia

quem era o filho da puta?

não tive tempo de ponderar

a besta mordeu meu peito e

seus dentes entre o carmim

seus dentate exibiam restos 0

de músculos rasgados

os pêlos eriçados

os olhos com um brilho alucinado

entre os caninos ela

saudava a nova presa

não existia misericórdia nen
maldade naquela boca cheia

em mim apenas um tórax

oco e infeccionado 


\section{a neblina}

nossa atmosfera particular era

a cidade e a neblica daquele

disco meio solidão neon de guilherme

arantes

estar com você e posteriormente

pensar em voce era como que vagar

pelo centro de uma são paulo

vazia com um piano no meio da rua

por essa não ser a minha geografia e

nem a sua talvez aquilo tenha se

tornado algo como a nossa geografi

mas à qual só eu tinha acesso e a

a mbição para expedicionar

hoje quando penso em tudo isso

acho engraçadíssima a não

comoção que enfim me causas porque

não era a mor era

um boy do sul

talvez por isso meus lábios esboçam

um sorriso aliviado mas não

sem antes ouvir

o cantor perguntar qual qual de

vocês não acha belo quando

a neblina desce $\mathrm{e}$

tudo translúcido

\section{Poéticas}


o cigarro

tua lembrança proporciona

violenta gastura dentro de min

as entranhas em polvorosa

enojadas enraivecidas coitad

eu tentando consolá-las

digo calma minhas crianças

acho que pedem um cigarro

não entendem que parei

penso que se parecem comigo

ao menos expressam o mesn

desejo irrevogável furioso

mas também burro e bestial de

dividir um lucky strike com você 
paralelos

hoje cedo pensei em te ligar

perguntar das coisas saber

do trabalho e da tua cabeç

mas percebi que mais

sentido tinha escrever
um poema assim caladinho

sem interpelações e crossovers
afetivos sentimentais de

afetivos sentimentais de

consequências desconhecidas

então fiquemos assim

os dois proprietário

de hemisferios que

não mais se colidem

mas ainda coexistem

sob as mesmas coordenad

em que nos perdemos 